Int. J. Morphol.,

24(4):665-671, 2006.

\title{
Effect of Thyroxine and Propylthiouracil in Ehrlich Ascitic Tumor Cells
}

\author{
Efecto de la Tiroxina y Propiltiouracilo en las Células del Tumor Ascítico de Ehrlich \\ "Freitas, E. S.; *Leite, E. D.; **Silva, A. E.; "Ocarino, N. M.; "Ferreira, E.; *Gomes, M. G.; *** Cassali, G. D. \& ****Serakides, R. \\ FREITAS, E. S.; LEITE, E. D.; SILVA, A. E.; OCARINO, N. M.; FERREIRA, E.; GOMES, M. G.; CASSALI, G. D. \& \\ SERAKIDES, R. Effect of thyroxine and propylthiouracil in Ehrlich acitic tumor cells. Int. J. Morphol., 24(4):665-671, 2006. \\ SUMMARY:The main purpose of this study was to investigate the effect of thyroxine and PTU in ascitic Ehrlich tumor cells. \\ Tumor was implanted in 30 female mice distributed in three groups: treated with PTU, treated with thyroxine and control. Each group \\ received an intraperitoneal injection of neoplastic cells, pre-incubated with sterile solutions of PTU, thyroxine and distilled water, \\ respectively. On the fifth and seventh days after inoculation, animals received an intraperitoneal injection of the respective solutions. On \\ the tenth day after inoculation, animals were sacrificed. Volume of ascitic liquid, number of neoplastic cells/ml and percentage of viable \\ cells were determined. Ascitic liquid smears were carried out for tumor cytological evaluation. There was no difference among groups \\ regarding ascitic liquid and as for the number and viability of tumor cells. However, cells under the effect of thyroxine presented significantly \\ larger mean of nuclear diameter, size and number of nucleolus organizer regions. In this group, there was a predominance of clear, round \\ cells with abundant eosinophilic and very vacuolated cytoplasm with little defined edges. Under the PTU effect, tumor cells were small \\ with hyperchromatic nucleus and the same number of NORs as the control group. It was concluded that PTU and thyroxine have not \\ changed the number and viability of cells after 10 days of tumor inoculation but they changed significantly cell characteristics. Whilst \\ thyroxine increases cell size and the number of NORs of ascitic Ehrlich tumor cells, PTU causes an opposite effect.
}

KEY WORDS: Cytology, Ehrlich tumor; Mouse; NORs; Propylthiouracil; thyroxine.

\section{INTRODUCCIÓN}

Transplantable experimental tumors have been used in studies of physical, chemical, viral and hormonal carcinogeneses (Bonamin, 1990). Ehrlich tumor is a transplantable neoplasia from a malign epithelium, which corresponds to mammary adenocarcinoma in female mice. When inoculated intraperitoneally it grows in an ascitic form and when inoculated subcutaneously it grows in the form of a solid tumor (Ehrlich, 1906).

This tumor has been used as a model for several studies, such as those to verify the influence of stress on cancer (Palermo-Neto et al., 2001; Palermo-Neto et al., 2003) and host's immunological response to tumor (Segura et al., 2000; Pinto, 2003), in the evaluation of tumor growth under the effect of ophidic toxins (Mady, 2002), vegetable extracts (Rajeshkumar et al., 2002), antiinflammatory drugs (Pal et al., 2001), chemical agents derived from fluoracil and cisplatin (Yoneda et al., 1999; Valadares \& Queiroz, 2002) and vitamines A and B1(Oloris et al., 2002).

Thyroid hormones are important cell growth, development and differentiation regulators. In order to assess the effect of thyroid dysfunctions on breast cancer prognosis, Ehrlich tumor has also been proposed as an experimental model. Studies have shown that hypothyroidism slows tumor growth even without changing malignity cell characteristics (Silva et al., 2004) and that hyperthyroidism promotes this growth (Ferreira, 2004). But it is not clear whether this effect is caused by thyroid dysfunction or by direct action of drugs used to experimentally induce hypo and hyperthyroidism.

There are no studies in the literature studied regarding direct effect of thyroxine, drug used to experimentally indu-

* DVM, MS. Departamento de Clínica e Cirurgia Veterinárias da Escola de Veterinária da Universidade Federal de Minas Gerais, Brazil.

** Departamento de Anatomia Patológica e Toxicologia da Escola de Veterinária da Universidade Federal da Bahia, Brazil.

*** DVM, MS, PhD. Departamento de Patologia Geral do Instituto de Ciências Biológicas da Universidade Federal de Minas Gerais, Brazil.

***** DVM, MS, PhD. Departamento de Clínica e Cirurgia Veterinárias da Escola de Veterinária da Universidade Federal de Minas Gerais, Brazil. 
ce hyperthyroidism or of propylthiouracil, used to induce hypothyroidism, on Ehrlich tumor. The purpose of this study was to evaluate the effect of these drugs on characteristics of ascitic Ehrlich tumor cells.

\section{MATERIAL AND METHOD}

Thirty 2-month-old female Swiss mice were used, kept in plastic cages (10 animals/cage), where they received commercial diet and water ad libitum and were maintained in a regimen of 12-hour light/12-hour dark. Animals were separated in three groups of 10 animals each. Group 1 treated with thyroxine; Group 2 treated with propylthiouracil (PTU) and Group 3 treatd with placebo (control group).

Tumor cell preparation included washing, counting, viability test and standardization of the cells. With sterile disposable syringes and needles, $3.0 \mathrm{~mL}$ of ascitic fluid was collected from a pre-inoculated mouse with Ehrlich tumor for ten days in cavidade peritonial. This fluid was centrifuged, supernatant was disregarded and cells were resuspended in physiological saline until a dense and clear liquid was obtained, corresponding to cell suspension with a minimum of fibrin and erythrocytes. Then tumor cells were counted and their viability test was performed, with a $95 \%$ of viability. The formula to determine the number of viable cells was deduced in accordance with Guerra (1983).

Before inoculation, tumor cells were pretreated with drugs for 30 minutes, in incubator at $37^{\circ} \mathrm{C}$, according to each group. Each $\mathrm{ml}$ of tumor cell suspension was pre-incubated with $1 \mathrm{~mL}$ of sterile thyroxine solution $(10 \mathrm{mg} / \mathrm{mL})$, PTU $(1 \mathrm{mg} / \mathrm{mL})$ and bidistilled water, as placebo, according to each treatment. At the end of incubation period, tumor cells were counted and cell viability test was performed again, exactly as it was described previously, with the purpose of evaluating the effect of incubation on neoplastic cells exposed to drugs. Mice received an abdominal injection containing $0.3 \mathrm{~mL}$ of cell suspension with $2.5 \times 10^{6}$ tumor cells, in order to obtain tumor in the ascitic form, remaining 10 days with this tumor. At days five and seven after inoculating tumor cells, animals from groups 1,2 and 3 received $0.3 \mathrm{~mL}$ thyroxine (10mg/animal), $0.3 \mathrm{ml}$ PTU (1mg/animal) and $0.3 \mathrm{~mL}$ distilled water, all of which were sterile, intra-peritoneally, respectively. In order to evaluate tumor growth curve, abdominal circumference was measured with the use of a measuring tape and animals were weighed immediately before and every two days after tumor inoculation, with a total of six measurements.

After 10 days of tumor implantation, animals were necropsied. Ascitic liquid was also collected in order to count tumor cells and determine their viability. Smears were carried out from the cell suspension obtained from each animal, then they were submitted to a panotico stain, in order to determine cell characterisctics, dark cells/clear cells ratio, nucleus/ cytoplasm ratio and mean diameter of neoplastic cell nuclei, in immersion objective. Mean nucleus diameter, was only evaluated in mononucleated neoplastic cells. Nucleolus organizer region was stained with silver (AgNORs), in accordance with a technique described by Ploton et al. (1986), modified by Aubele et al. (1994). Incubation was carried out in a humid and dark chamber at $40^{\circ} \mathrm{C}$ for 15 minutes. Characterizing and counting the number of AgNORs were carried out in immersion objective.

The number of cells and nuclei (to determine nucleus/ cytoplasm ratio and the number of NORs) and fields (to quantify the number of clear and dark cells) was determined using the technique of studying mean value instability variation regarding the sample where they came from. Standard deviation and variation coefficient of the variables studied were stable in about thirty cells and thirty fields/ slide/animal respectively.

Experimental delineation was completely at random with three treatments and ten repetitions/treatment. Data were submitted to variance analysis using test SNK to compare means (Sampaio, 1998).

\section{RESULTS}

In the beginning of the treatment, that is, before inoculating tumor cells, up to the end of the experiment, there was no significant difference of weight among animals (Table I). However, PTU-treated animals presented significantly smaller abdominal circumference on the second day of tumor growth evaluation, but this result has not repeated in the following measurements (Table II). There was no significant difference regarding ascitic liquid volume, cell number and viability among groups (Table III).

Characteristics of Ehrlich tumor cells differed among groups. In the group treated with thyroxine there was a significantly smaller number of dark cells. In this group, a predominance of clear and round cells with abundant, eosinophilic, quite vacuolated cytoplasm with little defined edges, large nuclei, sometimes being multinucleated (Figure 1b). In the group treated with PTU, the opposite occurred, that is, a significantly smaller number of clear cells with predominance of dark cells. Most cells were round with moderate, basophilic cytoplasm, with a few vacuoli, defined 


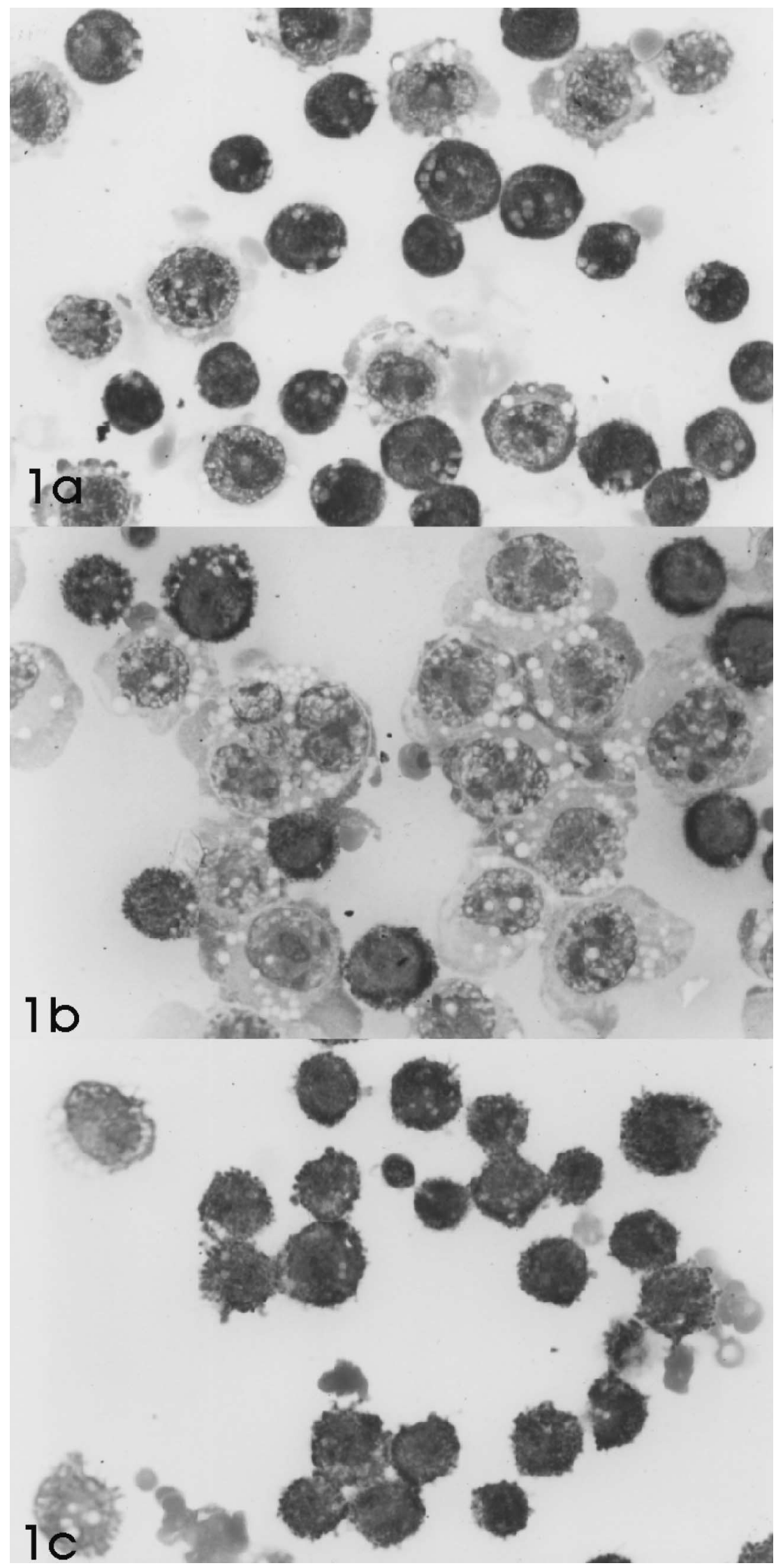

Fig. 1. Smears of the ascitic liquid cells of ascitic Ehrlich tumor in female mice. Panotico stain, 1071'.

a) Control group. Prevalence of cells with moderate cytoplasm and nuclear volume and few vacuoles.

b) Group treated with thyroxine. Cells round, with abundant cytoplasm and very vacuolated, bigger nuclei.

c) Group treated with propylthiouracil. Cells round, with smaller cytoplasm with few vacuoles.

edges and hyperchromatic nuclei varying from oval to round ones (Figure 1c). Neoplastic cells from the control group presented cytoplasmic and nuclear volume smaller when compared to the group treated with thyroxine and larger than the group treated with PTU (Fig. 1a). Morphometric analysis corroborated differences among groups as for cell and nucleus size (Table IV).

Nucleolus organizer regions (NORs) were small and distributed among nuclei and nucleoli in cells both from the control group and in those under thyroxine effect (Figs. 2a and b). In PTU-treated cells, NORs were larger and concentrated in the nucleolus (Fig. $2 c)$. The number of NORs was significantly higher only in cells under thyroxine action (Table IV).

In tumor cells treated with thyroxine, no increase was observed in nucleus/cytoplasm ratio, as there was an increase, not only in the nucleus but also in the entire cell (Table IV).

Regardless the group, no metastases were observed in spleen, liver, heart, lungs or even in abdominal lymph nodes. There was only a large amount of neoplastic cells under these organs capsule, which does not characterize metastasis. 


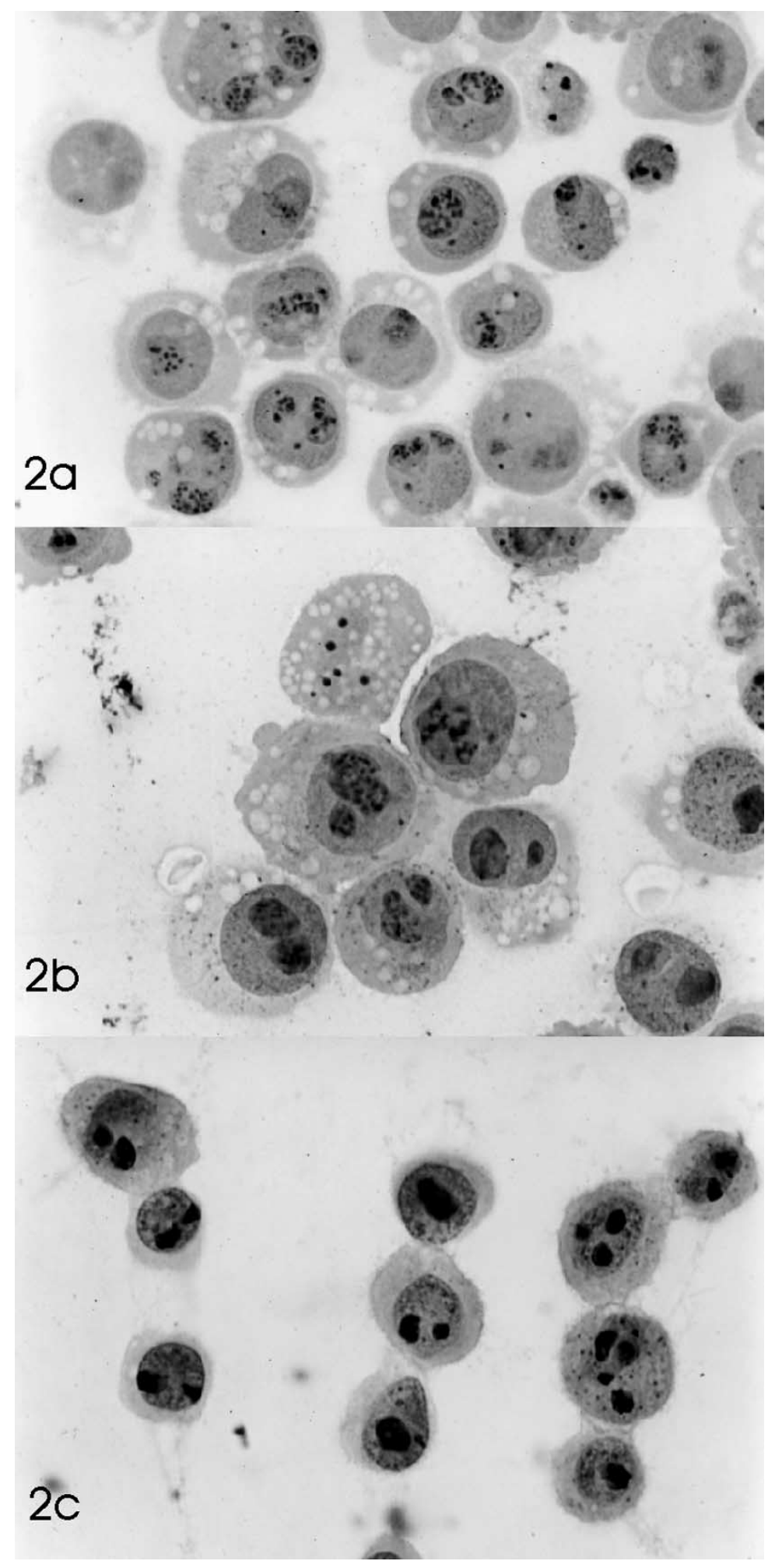

Fig. 2. Smears of the ascitic liquid cells of ascitic Ehrlich tumor in female mice. Impregnation of AgNOR, 1607'. a) Control group. Nucleoli organizer regions (NORs) small thoroughly filling the nucleus and nucleolus. b) Group treated with thyroxine. NORs similar the control group but in smaller number. c) Group treated with propylthiouracil. NORs larger, more concentrated in the nucleolus and in small number.

\section{DISCUSSION}

PTU-treated animals presented significantly smaller abdominal circumference only on the second day of tumor growth evaluation. This is probably because only after incubating tumor cells with the respective drugs, which was carried out before inoculation, there was a decrease in the viability of cells treated with PTU when compared to those incubated with thyroxine and with placebo (data not shown). This fact possibly explains why growth of tumor cells treated with PTU decreased on the second day after inoculation. However, PTU only decreased cell viability in the period of drug incubation, with no difference among groups regarding viable cells in the end of the experiment.

The production of ascitic liquid in Ehrlich tumor is said to occur due to increased capillary permeability present in peritoneal cavity (Senger et al., 1983). This vascular change occurs due to increased receptor expression for autocrine motility factor (AMF). AMF link to its receptor induces angiogenesis and changes endothelial cell morphology, causing subsequent increase of vascular permeability with increased amount of ascitic liquid (Funasaka et al., 2002). This mechanism does not seem to be affected by treatments, as there was no significant difference among groups regarding ascitic liquid volume. Number of NORs was significantly larger in cells under thyroxine action. NORs quantification, chromosomal DNA loops where ribosomal genes are coded, have been widely used as an indicator of cell proliferation, presenting significant value, both diagnostic and prognostic, in tumor pathology (Rüschoff et al., 1994; Cia et al., 1999; Metze et al., 1999; Metze et al., 2000). NORs have awakened interest as its number in the nucleus has been significantly larger in neoplastic cells when compared to normal, reactive or benign neoplastic cells (Derenzine, 2000).

Cell pleomorfism and the presence of several nucleoli and binucleated cells are also important characteristics of a tumor malignity (Brasileiro Filho, 2004). Although they have all been present in tumor cells treated with thyroxine, no increase was observed in nucleus/cytoplasm ratio, another important characteristic of malign neoplastic cells. In cells treated with thyroxine 
Table I. Weight $(\mathrm{g})$ (mean \pm SD) in female mice, control, treated with thyroxine and treated with propylthiouracil with ascitic Ehrlich tumor in day 0 until day 10.

\begin{tabular}{lccc}
\hline Weigth & \multicolumn{1}{c}{ Group } & \\
& Control $(\mathrm{n}=10)$ & Thyroxine $(\mathrm{n}=10)$ & Propylthiouracil $(\mathrm{n}=10)$ \\
Day before inoculation & $32.81 \pm 1.58 \mathrm{a}$ & $33.20 \pm 2.36 \mathrm{a}$ & $31.93 \pm 1.71 \mathrm{a}$ \\
Day 2 after inoculation & $29.42 \pm 9.09 \mathrm{a}$ & $31.83 \pm 1.99 \mathrm{a}$ & $31.45 \pm 1.81 \mathrm{a}$ \\
Day 4 after inoculation & $33.25 \pm 1.76 \mathrm{a}$ & $34.10 \pm 2.01 \mathrm{a}$ & $33.83 \pm 2.49 \mathrm{a}$ \\
Day 6 after inoculation & $34.82 \pm 1.99 \mathrm{a}$ & $37.41 \pm 3.03 \mathrm{a}$ & $37.18 \pm 3.27 \mathrm{a}$ \\
Day 8 after inoculation & $39.41 \pm 1.94 \mathrm{a}$ & $40.12 \pm 2.20 \mathrm{a}$ & $39.54 \pm 4.39 \mathrm{a}$ \\
Day 10 after inoculation & $39.84 \pm 2.63 \mathrm{a}$ & $38.80 \pm 2.95 \mathrm{a}$ & $38.81 \pm 4.75 \mathrm{a}$ \\
\hline
\end{tabular}

* Different letters in the same row indicate a statistically significant difference $(\mathrm{p}<0.05)$

Table II. Abdominal circumference $(\mathrm{cm})$ (mean \pm SD) in female mice, control, treated with thyroxine and treated with propylthiouracil with ascitic Ehrlich tumor in day 0 until day 10.

\begin{tabular}{lccc}
\hline & & Group & \\
Measurements day & Control $(\mathrm{n}=10)$ & Thyroxine $(\mathrm{n}=10)$ & Propylthiouracil $(\mathrm{n}=10)$ \\
\hline Day 0 before inoculation & $8.11 \pm 0.31 \mathrm{a}$ & $8.00 \pm 0.29 \mathrm{a}$ & $7.88 \pm 0.25 \mathrm{a}$ \\
Day 2 after inoculation & $7.87 \pm 0.21 \mathrm{a}$ & $7.65 \pm 0.17 \mathrm{a}$ & $7.49 \pm 0.33 \mathrm{~b}$ \\
Day 4 after inoculation & $8.07 \pm 0.22 \mathrm{a}$ & $7.94 \pm 0.20 \mathrm{a}$ & $8.10 \pm 0.26 \mathrm{a}$ \\
Day 6 after inoculation & $8.29 \pm 0.34 \mathrm{a}$ & $8.35 \pm 0.57 \mathrm{a}$ & $8.53 \pm 0.41 \mathrm{a}$ \\
Day 8 after inoculation & $9.58 \pm 0.32 \mathrm{a}$ & $9.44 \pm 0.32 \mathrm{a}$ & $9.31 \pm 0.49 \mathrm{a}$ \\
Day 10 after inoculation & $10 \pm 0.37 \mathrm{a}$ & $10.16 \pm 0.52 \mathrm{a}$ & $9.79 \pm 0.66 \mathrm{a}$ \\
\hline
\end{tabular}

* Different letters in the same row indicate a statistically significant difference $(\mathrm{p}<0.05)$

Table III. Measured variables in ascitic Ehrlich tumor (mean \pm SD) in female mice, control, treated with thyroxine and treated with propylthiouracil with ascitic Ehrlich tumor in day 0 until day 10

\begin{tabular}{lccc}
\hline & & Group & \\
Variable & Control $(\mathrm{n}=10)$ & Thyroxine $(\mathrm{n}=10)$ & Propylthiouracil $(\mathrm{n}=10)$ \\
\hline Ascitic liquid volume $(\mathrm{ml})$ & $6.75 \pm 1.97 \mathrm{a}$ & $8.09 \pm 2.28 \mathrm{a}$ & $7.54 \pm 2.54 \mathrm{a}$ \\
$\mathrm{N}^{\circ}$ of tumor cells $/ \mathrm{ml}$ & $143.25 \pm 41.9 \mathrm{a}$ & $116.55 \pm 32.05 \mathrm{a}$ & $127 \pm 35.47 \mathrm{a}$ \\
$\%$ of viable tumor cells $/ \mathrm{ml}$ & $95.98 \pm 2.59 \mathrm{a}$ & $96.39 \pm 1.50 \mathrm{a}$ & $96.31 \pm 1.85 \mathrm{a}$ \\
\hline
\end{tabular}

*Different letters in the same row indicate a statistically significant difference $(\mathrm{P}<0.05)$

Table IV. Nucleoli organizer regions (NORs) number, ratio dark/clear cells, mean nuclear diameter (mm), mean cell diameter $(\mathrm{mm})$ and ratio nucleus/cytoplasm (mean $\pm \mathrm{SD}$ ) in smears of ascitic Ehrlich tumor in female mice, control, treated with thyroxine and treated with propylthiouracil

\begin{tabular}{lccc}
\hline & & Group & \\
Variable & Control $(\mathrm{n}=10)$ & Thyroxine $(\mathrm{n}=10)$ & Propylthiouracil $(\mathrm{n}=10)$ \\
\hline $\mathrm{N}^{\circ}$ of NOR s/nucleus & $10.95 \pm 5.34 \mathrm{~b}$ & $19.16 \pm 5.16 \mathrm{a}$ & $9.63 \pm 3.17 \mathrm{~b}$ \\
$\mathrm{~N}^{\circ}$ of dark cells/field & $28.59 \pm 13.14 \mathrm{a}$ & $19.22 \pm 12.23 \mathrm{~b}$ & $35.76 \pm 13.18 \mathrm{a}$ \\
$\mathrm{N}^{\circ}$ of clear cells/field & $13.27 \pm 4.59 \mathrm{a}$ & $11.09 \pm 5.042 \mathrm{a}$ & $7.35 \pm 2.99 \mathrm{~b}$ \\
Ratio of dark/clear cells/field & $2.751 \pm 2.225 \mathrm{bc}$ & $2.023 \pm 1.327 \mathrm{c}$ & $5.747 \pm 3.690 \mathrm{a}$ \\
Mean nuclear diameter (_m) & $21.18 \pm 1.21 \mathrm{~b}$ & $24.56 \pm 2.37 \mathrm{a}$ & $15.65 \pm 4.02 \mathrm{c}$ \\
Mean cell diameter $\left(\_m\right)$ & $32.15 \pm 1.98 \mathrm{~b}$ & $38.99 \pm 2.33 \mathrm{a}$ & $28.87 \pm 1.12 \mathrm{c}$ \\
Ratio of nucleus/cytoplasm & $0.66 \pm 0.04 \mathrm{a}$ & $0.63 \pm 0.08 \mathrm{a}$ & $0.54 \pm 0.15 \mathrm{a}$ \\
\hline
\end{tabular}

$*$ Different letters in the same row indicate a statistically significant difference $(\mathrm{p}<0.05)$

there was an increase, not only in the nucleus but in the whole cell. Another intriguing factor is why there was no significant difference among groups regarding the number of neoplastic cells. Whether NORs quantification has been pointed out as a good indicator of cell proliferative activity and whether thyroxine treated cells presented an increased number of NORs, it should be investigated whether there was a simultaneous increase of proliferation rate and cell apoptosis.
Neoplastic cell exposure to thyroxine changed cell parameters, pointed out as important malignity characteristics. This may be the explanation for a higher speed of solid Erhlich tumor growth in the hyperthyroid state (Ferreira et al., 2004) . But, PTU action on tumor cells was in contrast to hypothyroidism, induced by this drug (Silva et al.). Tumor cells treated with PTU were smaller and with larger NORs and in a smaller number, exactly in contrast to 
what was observed in Ehrlich tumor in hypothyroid mice(Silva et al.). In the study of Silva et al., thyroid hypofunction delayed tumor growth, without decreasing tumor cells malignity. Thus, the effect of direct PTU administration on Ehrlich tumor cells differs from the effect caused by hypothyroidism.

Several types of antineoplastic drugs, such as, antimetabolic, alkaloid and antibiotic have been developed and used against malign tumors in humans. Among antimetabolic drugs, BOF-A2, a 5-fluoracil derivative, PTU analog, has been used to treat carcinomas and its action decreases tumor growth by inhibiting DNA synthesis and inducing apoptosis (Yoneda et al.).

In conclusion, PTU and thyroxine even without changing the number and viability of cells after 10 days of tumor inoculation changed significantly cell characteristics. Whereas thyroxine increases cell size and the number of NORs of ascitic Ehrlich tumor cells, PTU causes an opposite effect.

FREITAS, E. S.; LEITE, E. D.; SILVA, A. E.; OCARINO, N. M.; FERREIRA, E.; GOMES, M. G.; CASSALI, G. D. \& SERAKIDES, R. Efecto de la tiroxina y propiltiouracilo en las células del tumor ascítico de Ehrlich. Int. J. Morphol., 24(4):665-671, 2006.

RESUMEN: El propósito principal de este estudio ha sido investigar el efecto de la tiroxina y del propiltiouracilo (PTU) en las células del tumor de Ehrlich. El tumor fue implantado en 30 ratones hembras distribuidas en tres grupos: tratado con PTU, tratado con tiroxina y control. Cada grupo recibió una inyección intraperitoneal de células neoplásicas, pre-incubadas con las soluciones estériles de PTU, tiroxina y agua, respectivamente. En el quinto y séptimo días después de la inoculación, los animales recibieron una inyección intraperitoneal de las soluciones respectivas. En el décimo día después de la inoculación, se sacrificaron los animales. Fueron determinados el volumen de líquido ascítico, el número de células/ml y el porcentaje de células viables. Además se realizaron frotis del líquido ascítico para la evaluación de la citología del tumor. No hubo ninguna diferencia entre los grupos con respecto al volumen del líquido ascítico y el número y viabilidad de las células del tumor. Sin embargo, las células bajo el efecto de la tiroxina presentaron una media significativamente superior del diámetro nuclear, tamaño y número de regiones organizadoras de nucleélos. En este grupo, había un predominio de células claras, redondas con citoplasma abundante, eosinofílico y vacuolado con poca definición de los bordes. Bajo el efecto del PTU, las células del tumor eran pequeñas con el núcleo hipercromático y el mismo número de NORs como el grupo control. Se concluye que el PTU y tiroxina no afectaron el número y viabilidad de las células después de 10 días de inoculación del tumor, pero sí cambiaron las características celulares. Aunque la tiroxina aumenta el tamaño celular y el número de NORs de las celulas del tumor de Ehrlich, PTU causa efectos opuestos.

PALABRAS CLAVE: Citología; Tumor de Ehrlich; Ratón; NORs; propilthiouracil; Tiroxina.

\section{REFERENCES}

Aubele, M.; Biesterfeld, S. \& Derenzini, M. Guidelines of AgNOR quantitation. Zentralblatt für Pathol., 140:1078, 1994.

Bonamim, L.V. Stress \& Câncer. A influência do isolamento social no crescimento do tumor de Ehrlich em camundongos. São Paulo: Faculdade de Medicina Veterinária e Zootecnia da USP, 1990. 66p. Dissertação de Mestrado (rea - Patologia Experimental e Comparada).

Brasileiro-Filho, G. Bogliolo. Patologia. 3ed. Guanabara Koogan, Rio de Janeiro, 2004. pp173-234.

Cia, E.M.M.; Trevisan, M. \& Metze, K. Argyrophilic nucleolar organizer region (Ag-NOR) technique: a helpful tool for differential diagnosis in urinary cytology. Cytopathol., 10:30-9, 1999.
Derenzini, M. The AgNORs. Micron., 31:117-20, 2000.

Ehlich, P. Eperimentelle carcinomstudien na Mäusen. Arb. Inst. Exp. Ther. Frakfurt., 1:78-80, 1906.

Ferreira E.; Lima, A.; Serakides, R.; Calliari, M.; Cassali, G. D. Study of the influence of the hyperthyroidism in association with the castration in the development of the tumor de Ehrlich. 12th Annual Meeting of the Portuguese Society of Animal Pathology jointly with 16th Annual Meeting of the Spanish Society of Veterinary Pathology. Nova Famalicão-Portugal, Junho de 2004.

Funasaka, T.; Haga, A.; Raz, A.; Nagase, H. Tumor autocrine motility factor induces hyperpermeability of endothelial and mesothelial cells leading to accumulation of ascites fluid. Biochem. Biophs Res. Comm., 293:192-200, 2002. 
Guerra, J.L. Aspectos do processo inflamatório em camundongos portadores do tumor de Ehrlich. São Paulo: Faculdade de Medicina Veterinária e Zootecnia da USP, 1983. Tese de doutorado.

Mady, E.A. Antitumor and biochemical effects of Echis coloratus Crude venon on Ehrlich Ascite Carcinoma cells in vivo. J. Venon. Anim. Toxins, 8: 283-96, 2002.

Metze, K.; Chiari, A. C.; Andrade, F. L. \& Lorand-Metze, I. Changes in AgNOR configurations during the evolution and treatment of chronic lymphocytic leukemia. Hematol. Cell Therapy., 41:205-10, 1999.

Metze, K.; Lobo, A.M.; Lorand-Metze, I. Nucleolus organizer regions (AgNORs) and total tumor mass are independent prognostic parameters for treatment-free period in chronic lymphocytic leukemia. Int. J. Cancer (Pred. Oncol.), 89:440-3, 2000.

Oloris, S. C. S.; Dagli, M. L. Z. \& Guerra, J. L. Effect of bcarotene on the development of the solid Ehrlich tumor in mice. Life Sci., 71:717-24, 2002.

Pal, S.; Choudhuri, T.; Chattopadhyay, S.; Bhattacharya, A.; Datta, G.K.; Das, T. \& Sa, G. Mechanisms of curcumininduced apoptosis of Ehrlich's ascites carcinoma cells. Biochem. Biophys Res. Comm., 288:658-65, 2001.

Palermo-Neto, J; Massoco, C. A. \& Favare, R. C. Effects of maternal stress on anxiety levels, macrophage activity, and Ehrlich tumor growth. Neurotoxicol. and Terantol., 23:497-507, 2001.

Palermo-Neto, J. Massoco, C.A. \& Souza, W.R. Effects of physical and psychological stressors on behaviour, machophage activity, and Ehrlich tumor growth. Brain, Behaviour and Immunity., 17:43-54, 2003.

Pinto, F. C. H. Possíveis mecanismos envolvidos na supressão do tumor de Ehrlich em camundongos com alergia alimentar. Belo Horizonte: Escola de Medicina - UFMG, 2003. 91p. Tese de Doutorado (Área - Patologia).

Ploton, D.; Menager, M. \& Jeannesson, P. Improvement in the staining and the visualization of the argyrophlic proteins on nucleolar organizer regions at the optical level. Histochem. J., 18:5-14, 1986.

Rajeshkumar, N.V.; Joy, K.L.; Kuttan, G.; Ramsewak, R.S.; Nair, M. G. \& Kuttan, R. Antitumour and anticarcinogenic activity of Phyllanthus amarus extract. J. Ethnopharmacol., 81:17-22, 2002.

Rüschoff, J.; Fauser, G.; Knuchel, R.; Hofstadter, F. AgNOR quantification with special reference to staining patterns, Zentralbl Pathol., 140:23-30, 1994.

Sampaio, I. B. M. Estatística aplicada à experimentação animal. Belo Horizonte: FEP/MVZ, 1998. 211p.

Segura, J. A.; Barbero, L. G. \& Márquez, J. Ehrlich ascites tumour unbalances splenic cell populations and reduces responsiveness of T cells to Staphylococcus aureus enterotoxin B stimulation. Immunol. Lett., 74:111-5, 2000 .

Senger, D. R.; Galli, S. J.; Dvorak, A. M.; Perruzzi, C. A.; Harvey, V. S.; Dvorak, H. F. Tumor cells secrete a vascular permeability factor that promotes accumulation of ascites fluid. Science, 219:983-5, 1983.

Silva, A. E.; Serakides, R.; Ferreira, E.; Moraes, J. R. C.; Ocarino, N. M., Cassali, G.D. Efeito do hipotireoidismo no tumor de Ehrlich sólido em camundongos fêmeas castradas e não castradas. Arq. Bras. Endocrinol. Metabol., 48:867-74, 2004.

Valadares, M. C. \&Queiroz, M. L. S. The effect of a titanocene dichloride derivative, Ti IV (C5H5)2NCS2, on the hematopoietic response of Ehrlich tumour-bearing mice. Eur. J. Pharmacol., 439:35-42, 2002.

Yoneda, K.; Yamamoto, T.; Ueta, E.; Osaki, T. The inhibitory action of BOF-A2, a 5-fluorouracil derivative, on squamous cell carcinoma. Cancer Lett., 137:17-25, 1999.

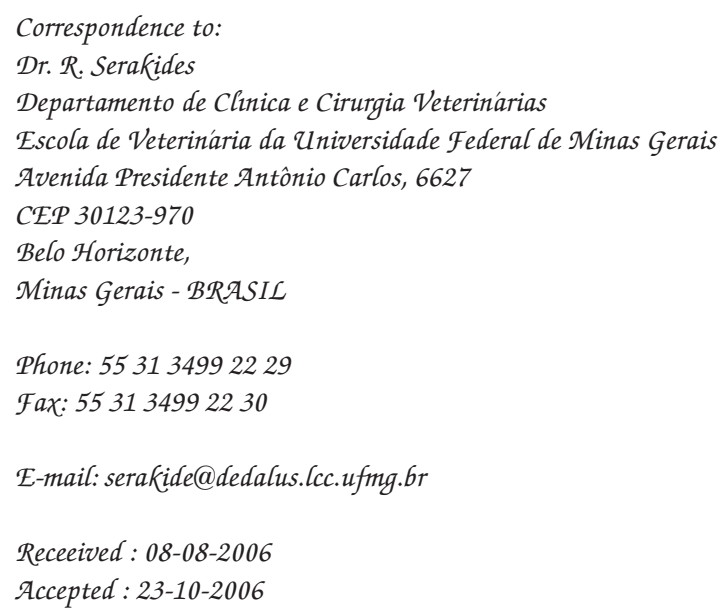

